\title{
Effects of Digital Story on Academic Achievement, Learning Motivation and Retention among University Students
}

\author{
Elif Aktaş ${ }^{1} \&$ Serap Uzuner Yurt ${ }^{2}$ \\ ${ }^{1}$ Faculty of Education, Department of Social sciences and Turkish Language Education, Recep Tayyip Erdoğan \\ University, Rize, Turkey \\ ${ }^{2}$ Vocational School of Health Services, Erzincan University, Erzincan, Turkey \\ Correspondence: Elif Aktaş, Faculty of Education, Recep Tayyip Erdoğan University, Rize, 53200, Turkey. Tel: \\ 90-046-4532-8454
}

Received: December 4, 2016

Accepted: January 3, 2017

Online Published: January 4, 2017

doi:10.5430/ijhe.v6n1p180

URL: http://dx.doi.org/10.5430/ijhe.v6n1p180

\begin{abstract}
The aim of this study was to determine the effect of the learning environment where digital stories are used as a learning material on the motivation, academic success, retention, and and students' opinions. The study was carried out with mixed method which is a combination of quantitative and qualitative research approach. The study was implemented in Recep Tayyip Erdoğan University Education Faculty Turkish Education Department. Participants included 61 students, 31 in experimental group and 30 in control group. To analyse the quantitative data; descriptive statistics, Student's t test and Paired sample t test were used. In analysis of qualitative data collected through semi-structured interviews, content analysis was performed. Study results showed that digital stories have a positive effect on the academic achievement, motivation and retention in the experimental group. In addition, the students in the experimental group were found to report a positive opinion on the application of digital stories.
\end{abstract}

Keywords: Digital story, Motivation, Academic achievement, Retention

\section{Introduction}

Technology, as in all areas, is integrated quickly into training activities. One of the approaches that will contribute to the integration of the teaching-learning process with technology is digital storytelling (Malita \& Martin, 2010; Robin, 2009).

Giving a new impulse to traditional storytelling, digital stories is a multifaceted educational and research tool which contextualizes knowledge in different disciplines related to the 21 st century skills with a postmodern approach (Huff, 2009; Robin, 2006). Computer and internet based multi-media have become one of the key areas used for storytelling recently. Digital storytelling is a new format of telling stories where stories are transferred to the online environment by bringing a new and artistic dimension to storytelling (Xu, Park \&Baek, 2011).

In its most general definition, digital story is a few minutes' narrative created to tell a short story on a particular issue by combining various multimedia tools such as visuals, videos, voice narration, and music (Robin, 2012; İnceelli, 2005). Digital stories as artistic, aesthetic and imaginative products are student-centered pedagogical materials which give students the opportunity to use their imagination (Sawyer \& Willis, 2011; Robin, 2009; İnceelli, 2005). They are employed to create a fiction convenient to the content in transmission and teaching of educational content (Rossiter \& Garcia, 2010).

Dijital storytelling is a technology application allowing teachers to use technology in the classroom efficiently and to create a good educational content. In this respect, it plays an important role for integration of education with technology and transfer such integration to the classroom environment. Digital storytelling allows computer users to do research on a topic, write a text using the information obtained, and gives the opportunity to make an interesting story out of it. Then this story is combined with different types of multimedia elements such as graphics, images, audio, text, video and music to make a video, and then viewed on the computer or on the web (Robin, 2009).

Digital stories are effective in raising students' interest and motivation towards the course, developing their emotional intelligence and communication skills by contributing to the process of learning by doing and experiencing, and their obtaining the 21st century literacy skills (Robin, 2006; Verdugo \& Belmonte, 2007). According to Dogan and Robin (2008), digital stories cover most of the 21st century literacy skills. Yüksel (2011) 
thinks that digital stories ensure development of their artistic skills as well as reflecting, higher-order thinking, social and language skills of students in the learning process. According to Sadik (2008), digital stories open a new horizon to curriculum and the students' learning experiences by means of the rich learning environment created in class.

One of the important contributions of digital storytelling is that beyond being passive listeners in the class, students are supposed to be guided, implement, contemplate and interpret during the process of creating and digitizing their scenarios (Barrett, 2006). Digital stories is a teaching tool that supports learning, encourages collaboration, develops creativity and decision-making process, and allows students to actively participate in the learning process (Dogan \& Robin, 2008; Robin, 2006). In this regard, digital stories are an effective practice to show what and how much learners understand in the learning environment. It is also thought to benefit from this practice in today's learning environments due to bringing to the forefront of the use of technology, supporting collaboration and developing critical and creative thinking (Barrett, 2006; Ohler, 2008; Yang \& Wu, 2012).

It is possible to take advantage of digital storytelling in the learning environment in various ways. These stories can be benefited in the learning environment in various ways. These stories can be created by students but also by teachers with the aim of drawing students' attention, providing new ideas or transferring the contents of teaching (Robin, 2006). Research shows that children can use the computer, Internet and other means of communication much better than their parents (Anastasiades, Vitalaki \& Gertzakis, 2008). This in turn facilitates the adaptation process of children to utilize the technology in e-learning environment and turns the use of information technologies into an important opportunity for them (Turgut \& Kışla, 2015).

According to Robin (2006), digital stories have six basic elements the perspective, interesting questions, the emotional content, the use of sound, economy and speed. In addition, the programs such as Windows MovieMaker, MS Powerpoint, MS Photostory, Imovie, and Scratch can be utilized for creating digital stories. There are also several websites helping the creation of digital stories by learners in the web environment and that support their team work in this process (Kocaman \& Karoğlu, 2015). According to Robin (2009), educational components of digital stories used in the education process are shown in Figure 1:

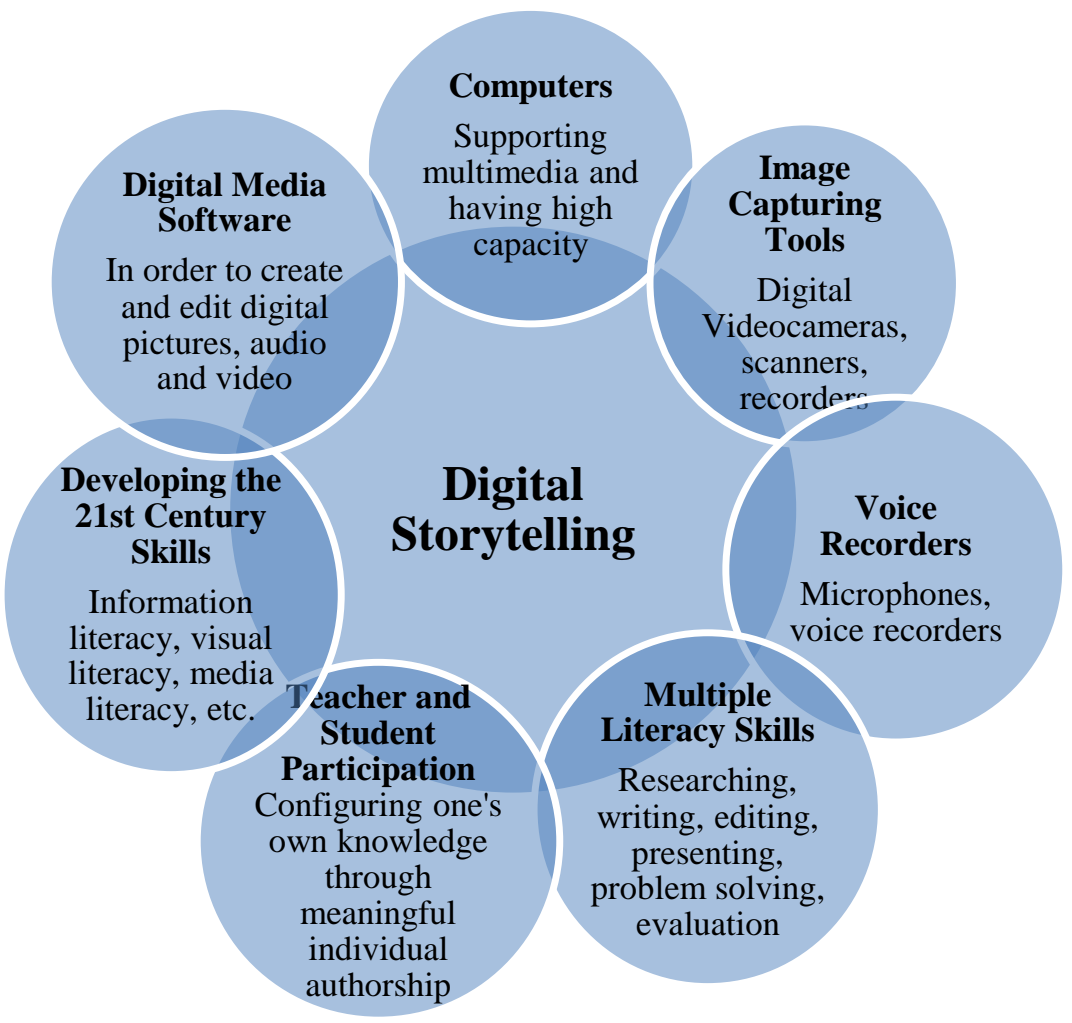

Figure 1. Educational components of digital stories

Miller (2009) suggests that digital storytelling allows higher-level thinking by increasing the interaction of students with texts in the narrative process, and helps them read in depth. Similarly, Robin (2008) notes that digital storytelling, along with the higher-level thinking and problem solving skills, is an effective approach in synthesizing, 
analyzing, evaluating and providing the knowledge information. According to Sadik (2008), digital storytelling encourages students to think more deeply about their topics or stories, help them personalize their experience and gives the opportunity to put forth their knowledge on that topic. Robin and Pierson (2005) think that digital stories enrich both the students and teachers' imagination and offer valuable experience for students and teachers in the creation of stories.

In the literature, there are studies on the use of digital stories with their educational advantages at all levels of education, starting from pre-school including higher education (Foley, 2013; Gyabak \& Godina 2011; Heo, 2009; Hung, Hwang \& Huang, 2012; Kocaman Karoglu, 2015b; Kearney 2011; Nguyen, 2011; Sadik, 2008; Verdugo \& Belmonte, 2007; Yang \& Wu, 2012; Karakoyun, 2014).

McLellan (2006) stresses that digital stories are also widely used in higher education due to their contribution to improving creative writing and communication skills. Present study aims to determine the effects of digital storytelling learning on academic achievement and learning motivation of university students.

\subsection{Problem and Research Questions}

In this study, the effects of digital stories on students' academic achievement, learning motivation, retention and students' opinions were investigated in the context of New Turkish Literature-II course. For this purpose, the main problem of the research was stated as "What are the effects of digital stories on university students' academic achievement, learning motivation, retention of knowledge and opinions in the New Turkish Literature-II course?" The sub-problems of the study were defined as follows:

1. Is there a significant difference between the mean scores of the students in the experimental group which used digital stories and the control group which used the present curriculum in the context of New Turkish Literature-II course?

2. Is there significant difference between the mean scores of learning motivation of students in the experimental group which used digital stories and the control group which used the present curriculum?

3. Is there significant difference between the mean scores of retention test in the experimental group which used digital stories and the control group which used the present curriculum in the context of New Turkish Literature-II course?

4. What are the views of the students in the experimental group, who used the digital stories, regarding the application?

\section{Method}

\subsection{The Research Design}

The study was carried out with mixed research method which means "a combination of qualitative and quantitative research techniques in a single study" (Johnson \& Christensen, 2004). According to Johnson and Christensen (2004), combining two or more research methods in one study, bearing strengths and weaknesses in mind, reduces the possibility of errors by researcher in the process. In this study, exploratory sequenced model was used as a mixed research method. In this model, researchers collect quantitative data in the first stage, analyze the findings and then build the second phase onto these (Creswell, 2014: 224). The purpose of the model is to use the qualitative data in order to describe quantitative findings in more detail. In present study, stage one involved collection and analysis of the quantitative data. Then it was intended to help explain the answers obtained during the quantitative stage by means of qualitative interviews.

In the quantitative model of this study, pretest-posttest control group experimental design was used. It is an experimental design that involves two groups, one experimental and one control group randomly formed. Both groups are pretested and posttested (Karasar, 2012). In the experimental group, digital stories were applied throughout the course, while the other group used the existing teacher-centered curriculum. In the qualitative part of the research, the study data were collected and analyzed through interview forms that had been developed to determine the views of the participants in the experimental group on the use of digital stories.

\subsection{Participants/Study Group}

Experimental and control group in the study were determined by random sampling method. The study was carried out in Recep Tayyip Erdoğan University Education Faculty Turkish Education Department during the 2015-2016 academic year spring term. In this scope, 31 students were selected from section 2/A for the experimental group, and 30 from section $2 / \mathrm{B}$ for the control group. 
For the qualitative phase of this research, sampling was limited to 30 students in the experimental group. This phase was performed with those participants because it was aimed to bring out the perceptions of digital storytelling throughout the whole process and conducting in-depth description related to the case.

\subsection{Data Collection Instruments}

In the study, the Achievement Test and Motivation Scale were used to collect quantitative data. In the collection of qualitative data, the Semi-Structured Interview Form was used.

\section{a. Achievement Test}

The Achievement Test was prepared in order to determine students' knowledge in the New Turkish Literature-II course. Prior to preparation of the test, a pool of multipe-choice questions was formed with 30 questions. The draft achievement test was submitted to two experts for review. Pilot study was carried out with 81 students at another Turkish university's education department attending the second grade.

As a result of the pilot application, KR-20 reliability coefficient of the "New Turkish Literature II" course academic achievement test was found to be 0,901 . Özçelik (2010: 184) recommends that reliability for tests used in education, apart from those with a small number of questions, should not fall under 0.80 , while not being above 0.90 in obtaining the measures that will form the basis for a serious decision for students.

Item discriminatory powers were calculated. As a result, 10 items were omitted as the discriminatory power is below 0,20 . Other 5 items with discriminatory power between 0,20 and 0,29 (item $7,18,24,26,29$ ) were used after revision. After the revision and correction, the achievement test was reduced to 20 items, and average difficulty was found to be 0,57 , and average discriminatory power as 0,42 .

\section{b. Motivation Scale}

In the study, the Motivation Scale was applied to find out the participants' motivational orientation. The scale was developed by Pintrich, Smith, Garcia and McKeachie (1991) as Motivated Strategies for Learning Questionnaire $(M S L Q)$ and adapted to Turkish by Büyüköztürk et al. (2004). The scale is composed of 31 items under six sub-scales: intrinsic goal orientation $(1,16,22,24)$, extrinsic goal orientation $(7,11,13,30)$, task value $(4,10,17,23$, $26,27)$, control belief about learning $(2,9,18,25)$, perceptions of self-efficacy for learning and achievement $(5,6$, $12,15,20,21,29,31)$ and test anxiety $(3,8,14,19,28)$.

The items of the scale are scored on a 7 point Likert scale, from 1 (Not at all true for me) to 7 (Very true for me). Crobnach alpha values calculated for internal consistency of the scale varied between .52 and .86 . The Cronbach alpha value for the entire of the scale was found to be 0,83 .

\section{c. Semi-Structured Interview Form}

Interview technique was used to determine the views of the students in the experimental group after the study. Interview is a mutual, interactive and discovery-driven process held to obtain individuals' information and ideas on various topics for a specific purpose by means of question and answer (Glesne, 2013). During the meeting, it is intended to gain about individuals' past, present and future attitudes, opinions and behaviors so as to describe the reality of the inner world and perspective of individuals (Patton, 2002).

During this research process, semi-structured interviews were conducted with students about the digital storytelling process in order to get more detailed information and to put forward the complete and in depth thoughts of the students about the process in the experimental group. This instrument allows more in-depth description of the participants' ideas, reducing misunderstandings, protection of individuality and assessment of the case from the perspective of participants (Cohen, Manion \& Morrison, 2011).

While developing the interview forms, the literature review was performed at first. Then, the three open-ended interview questions were prepared. To ensure the content validity of the form, one expert from the area of measurement and evaluation and three experts from the Turkish language education field were asked for their opinion. The final version of the form was prepared in the light of the recommendations of the experts. The form investigated whether the students were satisfied with the process of creating digital stories (and with what stage they were satisfied), whether they had difficulty in that process (degree of satisfaction) and asked students to explain benefits of digital stories with reasons.

\subsection{Process}

The application of the experimental study was realized by one of the researchers in the New Turkish Literature II course during the spring term of 2015-2016 academic year. Experimental and control groups were determined by 
random sampling. The participants were selected from Recep Tayyip Erdoğan University Turkish Education Department during the 2015 and 2016 academic year spring semester. On a random basis, 31 students registered in section 2/A were designated as the experimental group, and another 30 students from section 2/B were designated as the control group. In order to determine the baseline status of students in the experimental and control groups before the experimental process, the scales to be used for the research (Achievement Test and Motivation Scale) were applied as pretest. The two-week period before the implementation was taken by students to prepare for the main implementation. During that period, in the Instructional Technology and Material Design course, experimental group students were given presentations introducing digital storytelling application and sample applications were held. Due to the fact that the students had already taken Computer I and II and Instructional Technology and Material Design courses provided a positive contribution to the process of creating a digital history, the implementation was carried out smoothly. During the implementation, the students in the experimental group presented the digital stories they had prepared by themselves in the lesson, and made evaluations. On the other hand, the present curriculum was used in the control group, and the lesson was conducted under the guidance of the instructor. Lecturing and question-answer techniques were used in the course where students did not refer to any materials other than the coursebooks. As the four-week implementation ended, the Achievement Test and Motivation Scale were administered as a posttest.

The experimental procedure is illustrated in Figure 2 below.

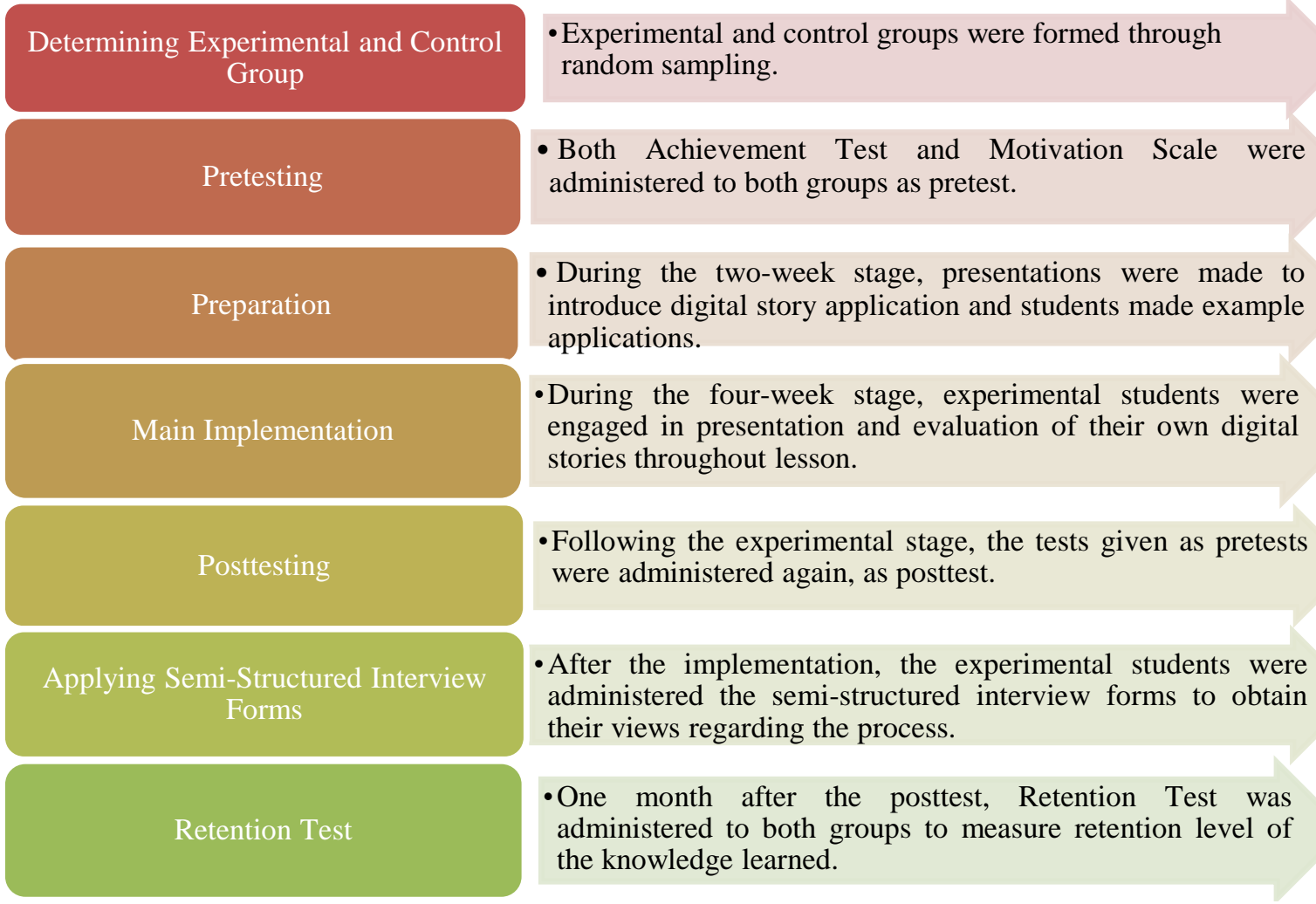

Figure 2. The experimental procedure

\subsection{Data Analysis}

Quantitative study data were analyzed with two different statistical analysis methods. The analyses were performed on computer by using SPSS for Windows 22.00.

1. Student $t$ test

2. Paired sample $t$ test

As a result of the power analysis, in order to find significant difference between the two average values when the amount of Type I error was 0.05 and the power of the test was 0.80 , the minimum sample size required for the study group was set at 18 .

In the analysis of the qualitative study data, content analysis was used. 


\section{Findings}

Comparative pretest scores of students in the experimental and control groups obtained from the Achievement Test and Motivation Scale are given in Table 1.

Table 1. Comparative Pretest Scores of Experimental and Control Groups in Achievement Test and Motivation Scale

\begin{tabular}{|c|c|c|c|c|c|c|}
\hline \multirow{2}{*}{ Scale and Sub-Scale } & \multicolumn{2}{|c|}{ Experimental Group } & \multicolumn{2}{|c|}{ Control GrouI } & & \multirow[b]{2}{*}{$\mathbf{p}$} \\
\hline & $\mathbf{M}$ & SD & $\mathbf{M}$ & SD & & \\
\hline Achievement Test & 57,17 & 9,973 & 56,67 & 9,034 & ,204 &, 500 \\
\hline Intrinsic Goal Orientation & 12,30 & 1,393 & 11,97 & 1,377 & ,932 & ,355 \\
\hline Extrinsic Goal Orientation & 15,47 & 2,097 & 14,93 & 1,484 & 1,137 & ,260 \\
\hline Task Value & 16,00 & 1,554 & 16,77 & 1,455 & 1,973 & 053 \\
\hline Control Belief about Learning & 11,70 & 1,512 & 11,33 & 1,749 & 869 & ,389 \\
\hline Perceptions of Self-Efficacy for Learning and Achievement & 22,03 & 1,938 & 21,23 & 1,794 & 1,659 & , 103 \\
\hline Test Anxiety & 26,87 & 1,925 & 26,47 & 1,795 & ,832 & ,409 \\
\hline Motivation Scale Total Score & 104,37 & 4,429 & 102,70 & 4,332 & 1,473 & , 146 \\
\hline
\end{tabular}

As a result of the data analysis; the difference between the experimental group and control group was found insignificant in average scores in the "Achievement Test" pretest $(\mathrm{t}=.204 \mathrm{p}=.500)$ and Motivational Sub-Scales including "Intrinsic Goal Orientation" ( $\mathrm{t}=, 932 \mathrm{p}=, 355)$, "Extrinsic Goal Orientation" $(\mathrm{t}=1,137 \mathrm{p}=, 260)$, “Task Value" ( $\mathrm{t}=1,973 \mathrm{p}=, 053)$, "Control Belief About Learning" ( $\mathrm{t}=, 869 \mathrm{p}=, 389)$, "Perceptions of Self-Efficacy for Learning and Achievement" $(\mathrm{t}=1,659 \mathrm{p}=, 103)$, "Test Anxiety" $(\mathrm{t}=, 832 \mathrm{p}=, 409)$, and total scores obtained from the Motivational Scale $(\mathrm{t}=1,473 \mathrm{p}=, 146)$.

Overall, no difference was found between average pretest scores of both groups in the "Achievement Test", as well as "Intrinsic Goal Orientation", "Extrinsic Goal Orientation", "Task Value", "Control Belief about Learning", "Perceptions of Self-Efficacy for Learning and Achievement", "Test Anxiety" sub-scales of the Motivational Scale and the total scores obtained from the Motivational Scale (Chart 1). These findings suggest that the groups were equivalent before the experimental procedure was applied.

Chart 1. Pretest Arithmetic Averages of Experimental and Control Group in Achievement Test and Motivational Scale

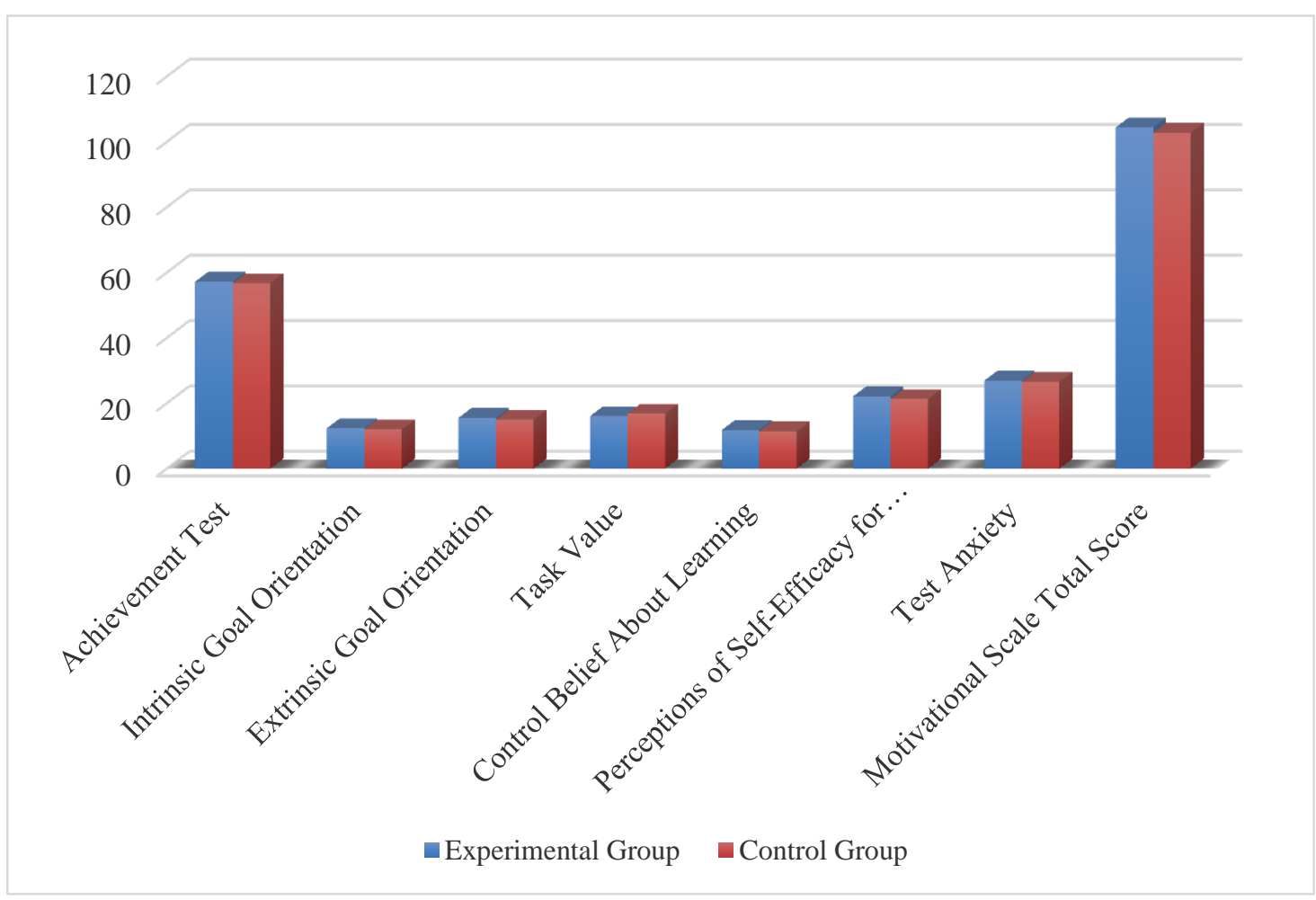


Comparative posttest scores of students in the experimental and control groups obtained from the Achievement Test and Motivation Scale are given in Table 2.

Table 2. Comparative Posttest Scores of Experimental and Control Groups in Achievement Test and Motivation Scale

\begin{tabular}{lllllll}
\hline & \multicolumn{3}{l}{ Experimental Group } & Control Grou & & \multirow{2}{*}{ p } \\
\cline { 2 - 7 } & $\mathbf{M}$ & SD & M & SD & & t \\
\hline Achievement Test & 80,33 & 9,371 & 67,67 & 7,626 & 5,742 &, 000 \\
Intrinsic Goal Orientation & 23,27 & 1,081 & 11,60 & 1,499 & 34,573 &, 000 \\
Extrinsic Goal Orientation & 22,90 & 1,561 & 15,17 & 2,167 & 15,859 &, 000 \\
Task Value & 32,03 & 1,866 & 15,73 & 1,552 & 36,784 &, 000 \\
Control Belief about Learning & 21,40 & 1,476 & 11,33 & 1,539 & 25,857 &, 000 \\
Perceptions of Self-Efficacy for Learning and Achievement & 44,40 & 2,774 & 19,73 & 2,791 & 34,333 &, 000 \\
Test Anxiety & 11,77 & 1,716 & 25,37 & 1,520 & 32,501 &, 000 \\
Motivation Scale Total Score & 155,77 & 4,644 & 98,93 & 5,146 & 44,911 &, 000 \\
\hline
\end{tabular}

Analysis of the posttest scores revealed that the experimental group was significantly better than the control group in the "Achievement Test" ( $\mathrm{t}=5,742 \mathrm{p}=.000)$, and sub-scales of the Motivational Scale such as "Intrinsic Goal Orientation" ( $\mathrm{t}=34,573 \mathrm{p}=, 000)$, "Extrinsic Goal Orientation" $(\mathrm{t}=15,859 \mathrm{p}=, 000)$, “Task Value" $(\mathrm{t}=36,784 \mathrm{p}=, 000)$, "Control Belief about Learning" ( $\mathrm{t}=25,857 \mathrm{p}=, 000)$, "Perceptions of Self-Efficacy for Learning and Achievement" $(\mathrm{t}=34,333 \mathrm{p}=, 000)$, "Test Anxiety" ( $\mathrm{t}=32,501 \mathrm{p}=, 000)$, and lastly total average scores in the Motivational Scale $(\mathrm{t}=44,911 \mathrm{p}=, 000)$.

As a result, the experimental group obtained significant posttest results in comparison to the other in all of the tested dimensions such as the "Achievement Test", and sub-scales of the Motivational Scale including "Intrinsic Goal Orientation", "Extrinsic Goal Orientation", "Task Value", "Control Belief About Learning", "Perceptions of Self-Efficacy for Learning and Achievement", "Test Anxiety", and the Motivational Scale total score (Chart 2).

Chart 2. Posttest Arithmetic Averages of Experimental and Control Group in Achievement Test and Motivational Scale

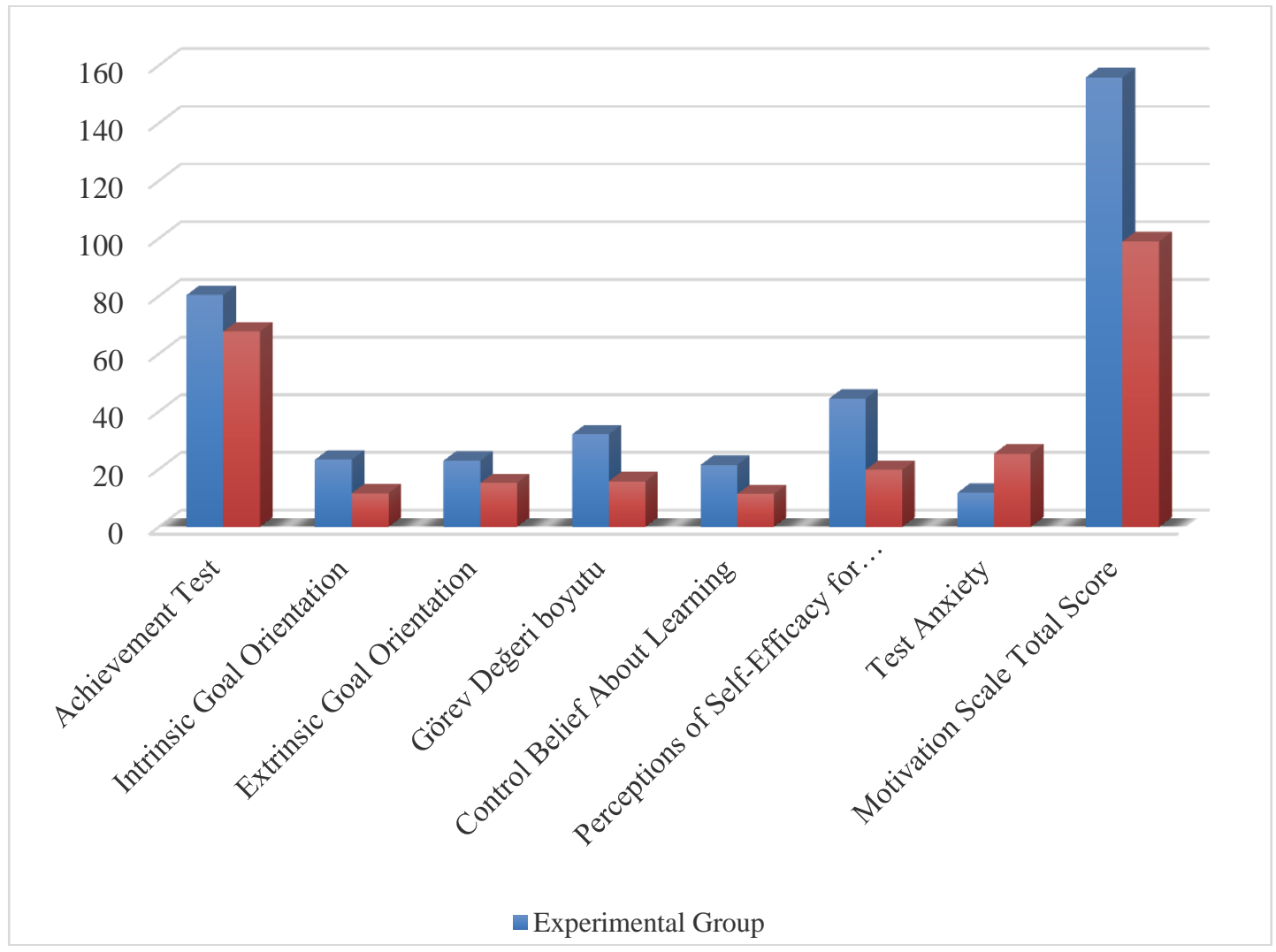


4 weeks after implementation of the experimental procedure, a follow-up test was applied to both groups. The scores are given in Table 3.

Table 3. Comparative Follow-Up Scores of Experimental and Control Groups in Achievement Test

\begin{tabular}{|c|c|c|c|c|c|c|}
\hline \multirow{2}{*}{ Scale and Sub-Scale } & \multicolumn{2}{|c|}{ Experimental Group } & \multicolumn{2}{|c|}{ Control Group } & & \multirow{2}{*}{$\mathbf{p}$} \\
\hline & $\bar{M}$ & SD & $\mathbf{M}$ & SD & & \\
\hline Achievement Test & 70,83 & 7,887 & 58,83 & 7,507 & 6,036 & ,000 \\
\hline
\end{tabular}

Data analysis showed that the experimental group obtained higher average scores from the "Achievement Test" follow-up assessment at significant level $(\mathrm{t}=6,036 \mathrm{p}=.000)$.

In other words, the experimental group was seen to have performed higher at the "Achievement Test" follow-up test which was applied 30 days after the experimental procedure (Chart 3).

Chart 3. Follow-Up Test Arithmetic Averages of Experimental and Control Group in Achievement Test After 30 Days

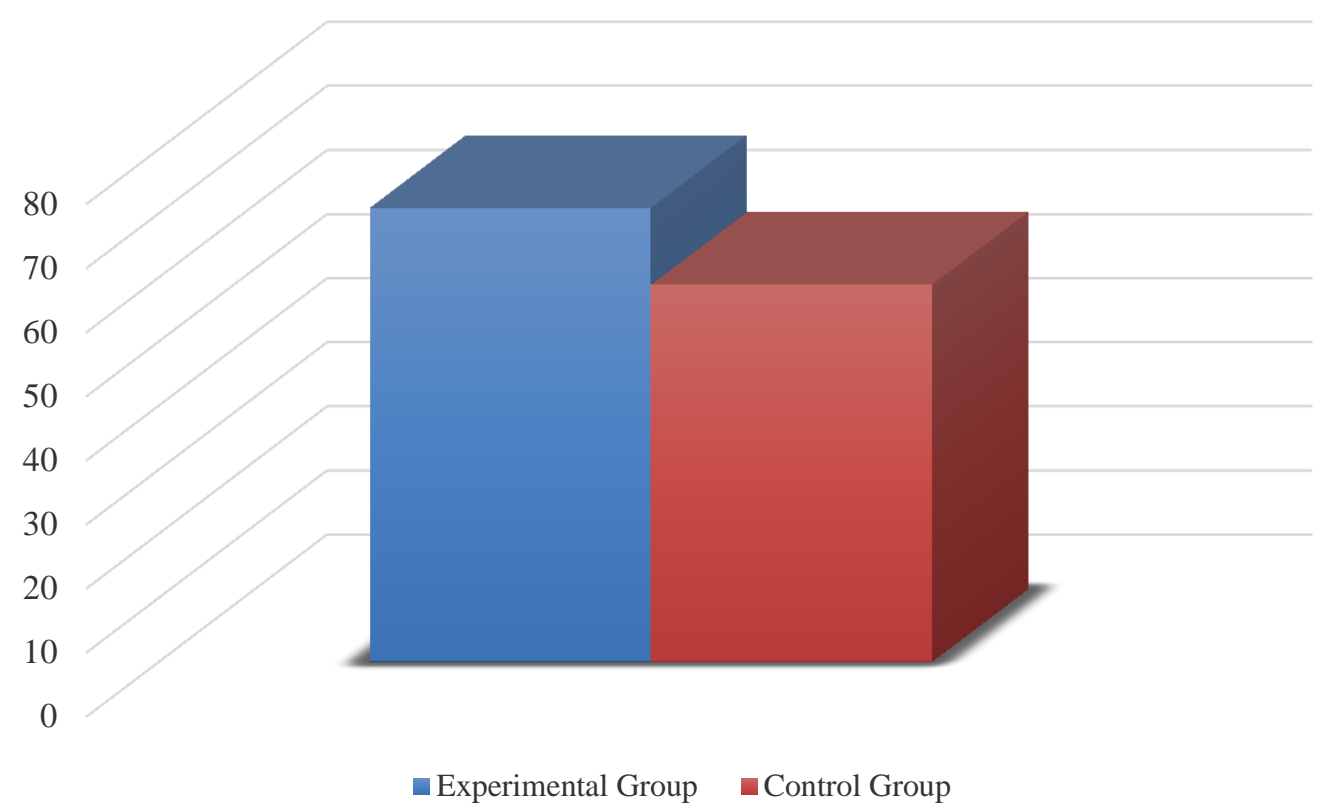

The pretest and posttest scores of the students in the experimental group obtained from the Achievement Test and Motivational Scale are compared in Table 4.

Table 4. Comparative Pretest-Posttest Scores of Experimental Group in Achievement Test and Motivation Scale

\begin{tabular}{|c|c|c|c|c|c|c|}
\hline \multirow{2}{*}{ Scale and Sub-Scale } & \multicolumn{2}{|c|}{$\begin{array}{l}\text { Experimental } \\
\text { Group }\end{array}$} & \multicolumn{2}{|c|}{ Control Group } & \multirow[t]{2}{*}{$\mathbf{t}$} & \multirow{2}{*}{$\mathbf{p}$} \\
\hline & $\mathbf{M}$ & SD & $\mathbf{M}$ & SD & & \\
\hline Achievement Test & 57,17 & 9,973 & 80,33 & 9,371 & 23,111 & 000 \\
\hline Intrinsic Goal Orientation & 12,30 & 1,393 & 23,27 & 1,081 & $-44,446$ &, 000 \\
\hline Extrinsic Goal Orientation & 15,47 & 2,097 & 22,90 & 1,561 & $-15,300$ &, 000 \\
\hline Task Value & 16,00 & 1,554 & 32,03 & 1,866 & $-32,559$ &, 000 \\
\hline Control Belief about Learning & 11,70 & 1,512 & 21,40 & 1,476 & $-28,568$ &, 000 \\
\hline Perceptions of Self-Efficacy for Learning and Achievement & 22,03 & 1,938 & 44,40 & 2,774 & $-35,728$ &, 000 \\
\hline Test Anxiety & 26,87 & 1,925 & 11,77 & 1,716 & 33,891 & ,000 \\
\hline Motivation Scale Total Score & 104,37 & 4,429 & 155,77 & 4,644 & $-41,429$ & ,000 \\
\hline
\end{tabular}


Examination of the pretest and posttest scores in the table above reveals that the students in the experimental group obtained higher scores from Achievement Test at posttest ( $\mathrm{t}=-23,111 \mathrm{p}=.000)$, also from the Motivational Scale, particularly Intrinsic Goal Orientation $(\mathrm{t}=-44,446 \mathrm{p}=.000)$, Extrinsic Goal Orientation $(\mathrm{t}=-15,300 \mathrm{p}=.000)$, Task Value $(\mathrm{t}=-32,559 \mathrm{p}=.000)$, Control Belief about Learning $(\mathrm{t}=-28,568 \mathrm{p}=.000)$, Perceptions of Self-Efficacy for Learning and Achievement $(\mathrm{t}=-35,728 \mathrm{p}=.000)$, Test Anxiety $(\mathrm{t}=33,891 \mathrm{p}=.000)$, and overall Motivational Scale $(\mathrm{t}=-41,429 \mathrm{p}=.000)$.

In general, the training on digital storytelling seems to have positive effects on the experimental group in connection with the Achievement Test, Intrinsic Goal Orientation, Extrinsic Goal Orientation, Task Value, Control Belief about Learning, Perceptions of Self-Efficacy for Learning and Achievement, Test Anxiety, and overall Motivational Scale (Chart 4).

Chart 4. Comparative Pretest-Posttest Scores of Experimental Group in Achievement Test and Motivation Scale

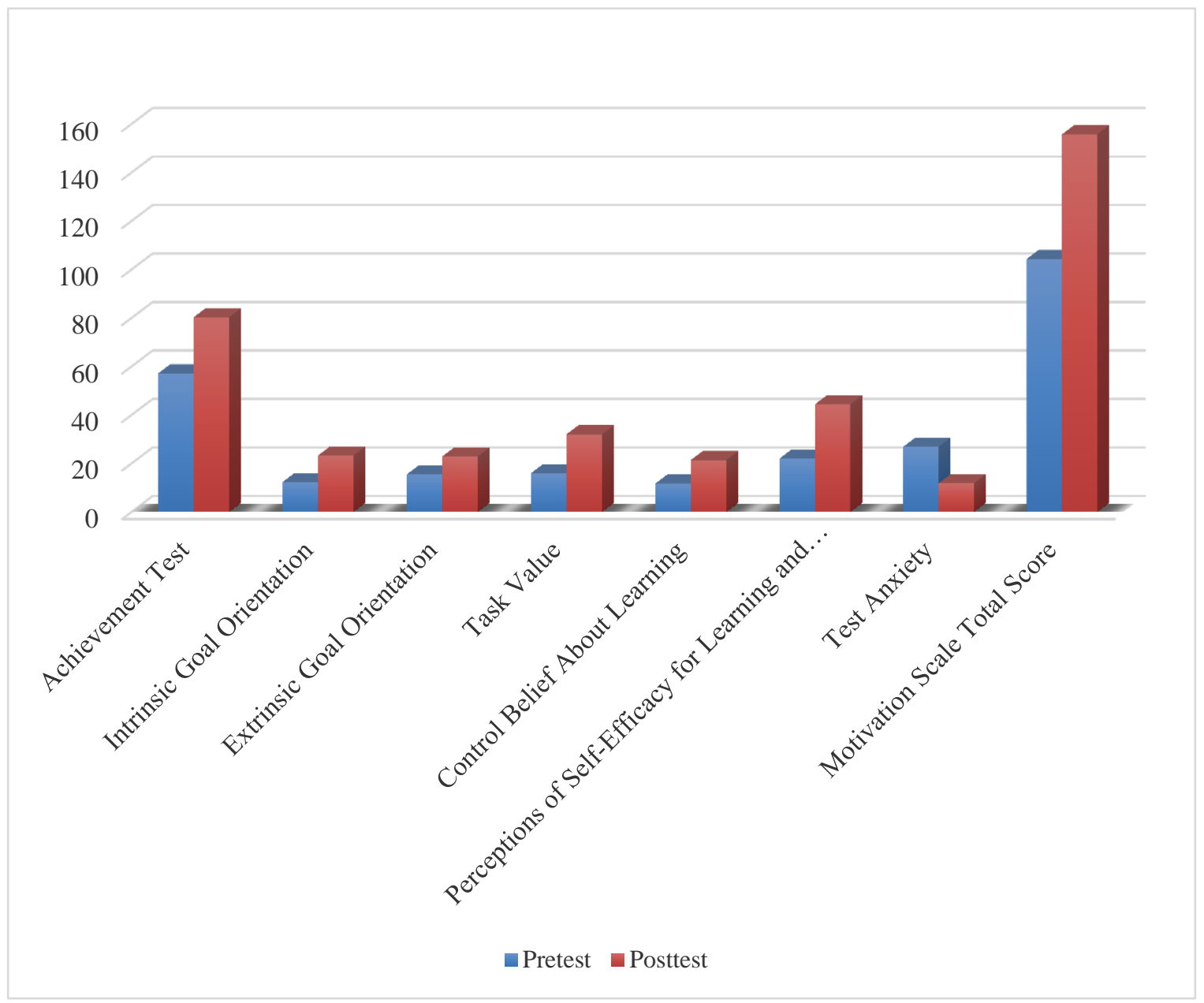

As regards to the control group, the scores in the Achievement Test and Motivational Scale at pretest and posttest are compared in Table 5. 
Table 5. Comparative Pretest-Posttest Scores of Control Group in Achievement Test and Motivation Scale

\begin{tabular}{lllllll}
\hline \multirow{2}{*}{ Scale and Sub-Scale } & \multicolumn{3}{l}{ Experimental Group } & \multicolumn{2}{l}{ Control Group } & \multirow{2}{*}{ p } \\
\cline { 2 - 6 } & $\mathbf{M}$ & SD & M & SD & & \\
\hline Achievement Test & 56,67 & 9,034 & 67,67 & 7,626 & $-11,330$ &, 000 \\
Intrinsic Goal Orientation & 11,97 & 1,377 & 11,60 & 1,499 &, 945 &, 352 \\
Extrinsic Goal Orientation & 14,93 & 1,484 & 15,17 & 2,167 &,- 498 &, 623 \\
Task Value & 16,77 & 1,455 & 15,73 & 1,552 & 2,417 &, 022 \\
Control Belief about Learning & 11,33 & 1,749 & 11,33 & 1,539 &, 000 & 1,000 \\
Perceptions of Self-Efficacy for Learning and Achievement & 21,23 & 1,794 & 19,73 & 2,791 & 2,801 &, 009 \\
Test Anxiety & 26,47 & 1,795 & 25,37 & 1,520 & 2,576 &, 015 \\
Motivation Scale Total Score & 102,70 & 4,332 & 98,93 & 5,146 & 3,734 &, 001 \\
\hline
\end{tabular}

It is seen in Table 5 that the difference between the pretest and posttes scores was significant for the former in the Achievement Test $(\mathrm{t}=-11,330 \mathrm{p}=.000)$; while it was insignificant in the sub-scales of Motivational Scale as Intrinsic Goal Orientation ( $\mathrm{t}=, 945 \mathrm{p}=.352)$, Extrinsic Goal Orientation $(\mathrm{t}=-, 498 \mathrm{p}=.623)$, and Control Belief about Learning $(\mathrm{t}=, 000 \mathrm{p}=1.000)$. However, the scores were found higher in pretest for the other sub-scales as Task Value $(\mathrm{t}=2,417$ $\mathrm{p}=.000)$, Perceptions of Self-Efficacy for Learning and Achievement $(\mathrm{t}=2,801 \mathrm{p}=.009)$, Test Anxiety $(\mathrm{t}=2,576$ $\mathrm{p}=.015)$, and overall Motivational Scale $(\mathrm{t}=3,734 \mathrm{p}=.001)$.

It seems that the training in the control group was a positive effect on Achievement Test scores; however, it had a negative effect on the sub-scales of Task Value, Perceptions of Self-Efficacy for Learning and Achievement, Test Anxiety and the overall Motivational Scale, while proving neutral for the remaining sub-scales as Intrinsic Goal Orientation, Extrinsic Goal Orientation, and Control Belief About Learning (Chart 5).

Chart 5. Comparative Average Pretest-Posttest Scores of Control Group in Achievement Test and Motivation Scale

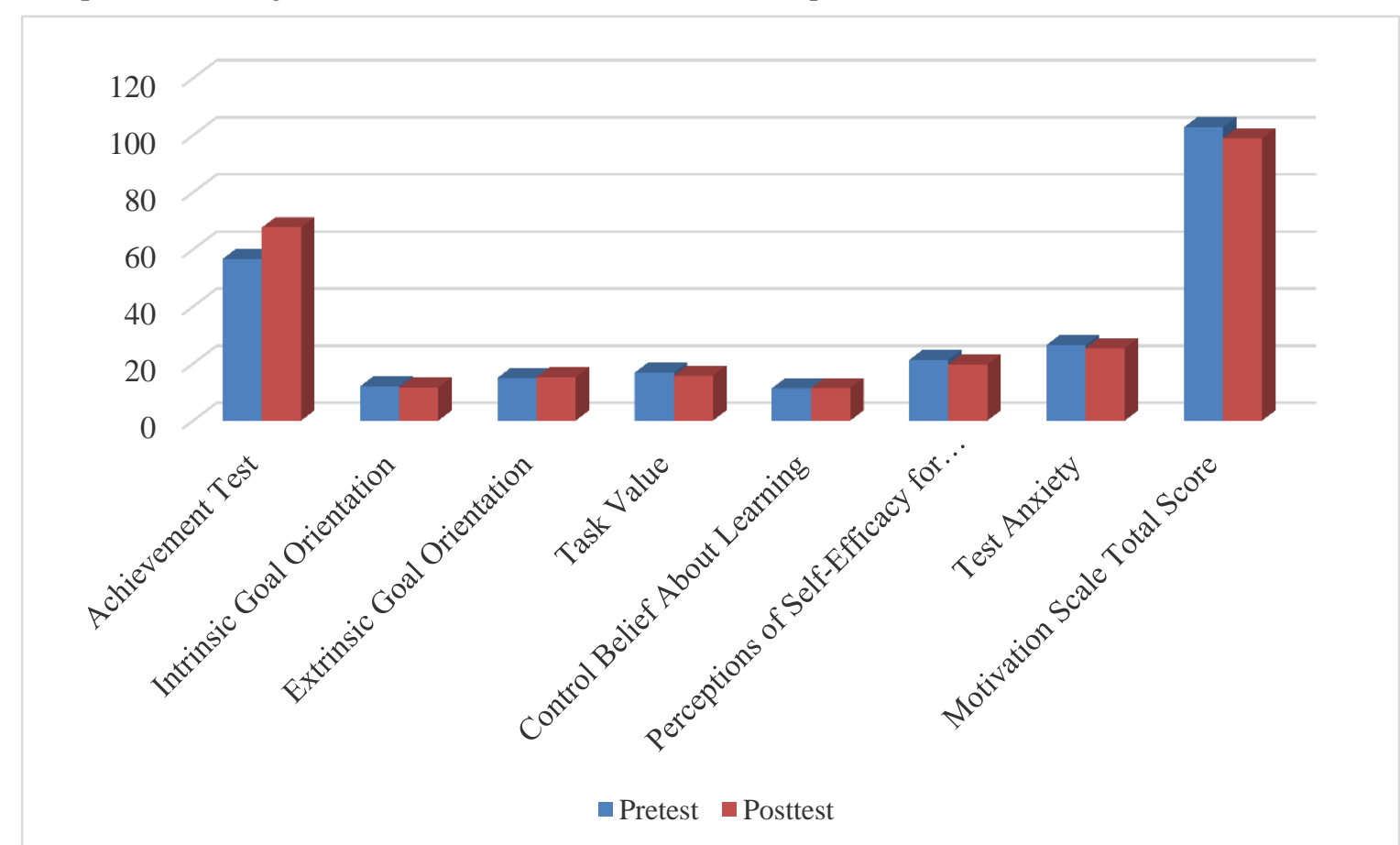

Table 6 displays the comparative posttest and follow-up test results obtained by experimental and control groups from the Achievement Test soon after the experiment and 30 days later. 
Table 6. Comparative Average Posttest - Follow-Up Test Scores of Experimental Group in Achievement Test

\begin{tabular}{|c|c|c|c|c|c|c|}
\hline & \multicolumn{2}{|c|}{ Posttest } & \multicolumn{2}{|c|}{ Follow-Up Test } & & \multirow{2}{*}{$\mathbf{p}$} \\
\hline & $\mathbf{M}$ & SD & $\mathbf{M}$ & SD & & \\
\hline Experimental Group & 80,33 & 9,371 & 70,83 & 7,887 & 13,714 & ,000 \\
\hline Control Group & 67,67 & 7,626 & 58,83 & 7,507 & 10,780 &, 000 \\
\hline
\end{tabular}

The table shows significant difference in the Achievement Test from posttest to follow-up test for students in the experimental group $(\mathrm{t}=13,714 \mathrm{p}=.000)$ and the control group, too $(\mathrm{t}=10,780 \mathrm{p}=.000)$. It is seen from the table that average follow-up scores of students were below the posttest scores in both groups.

It is seen that the students in both experimental and control group performed low in the Achievement Test during the Folow-Up Assessment 30 days later (Chart 6).

Chart 6. Comparative Average Posttest - Follow-Up Test Scores of Experimental and Control Groups in Achievement Test

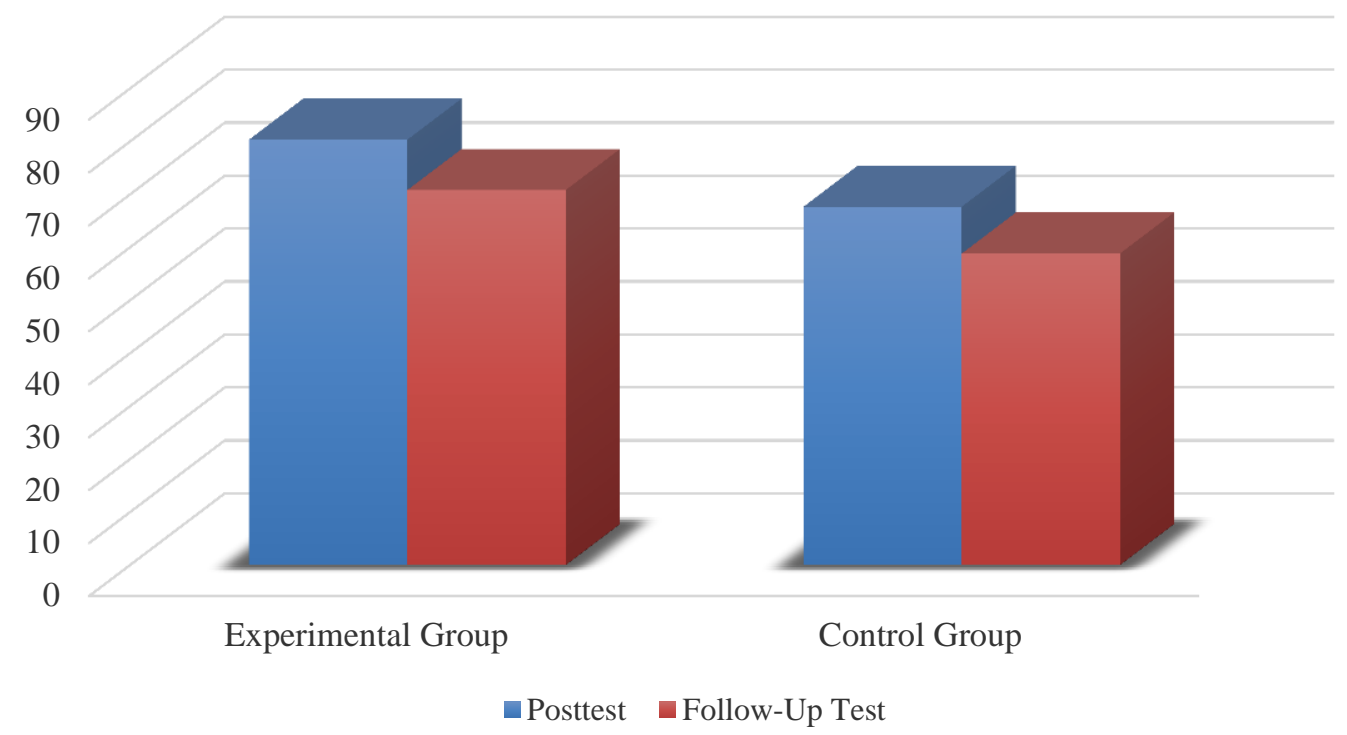

It can be inferred that the training provided for the experimental group was more effective than the traditional training given for the control group, and the effect of such training on performance decreases the allocated time for the course (Chart 7). 
Chart 7. Comparative Average Pretest - Posttest - Follow-Up Test Scores of Experimental and Control Groups in Achievement Test

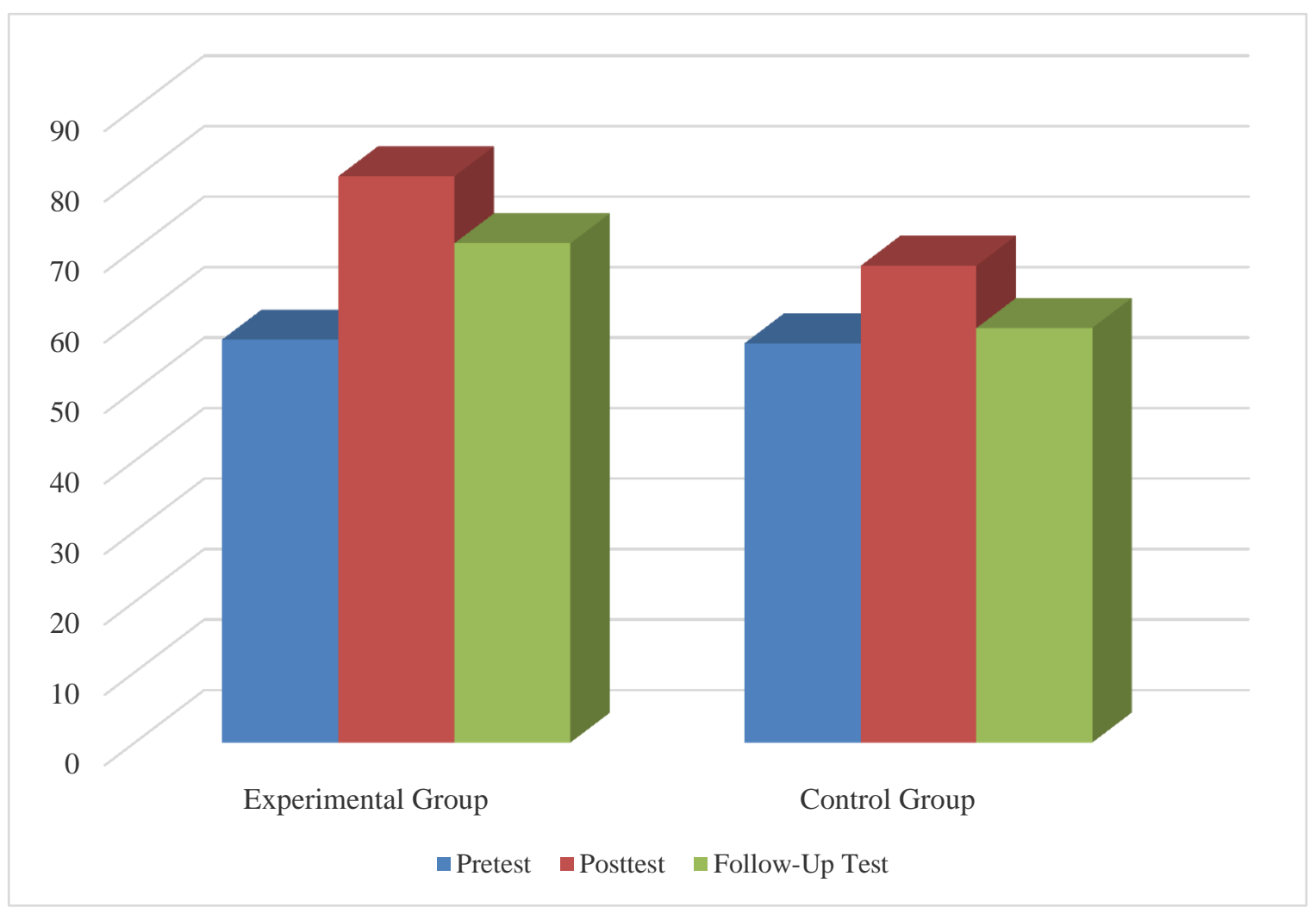

\section{Results of Frequency Analysis of the Interview Forms}

In the end of the experimental procedure, a semi-structured interview form was used to obtain opinions and comments of the students in the experimental group on digital story applications and to support the quantitative study data with qualitative data. The opinions obtained from forms were analyzed with content analysis and the study codes and themes were identified. The data were gathered under three headings in relation with three questions. Then, frequency analysis was performed.

Table 7. Student Views on Their Contentment with the Digital Storytelling Process

\begin{tabular}{|c|c|c|c|}
\hline Theme & Opinion/Code & $\mathbf{f}$ & $\%$ \\
\hline Visualization & $\begin{array}{l}\text { I enjoyed searching the net for visuals most while creating a story. (S3) } \\
\text { I had funny and lovely time during the visualization step. (S5) }\end{array}$ & 11 & $\% 35.4$ \\
\hline Selecting Music & $\begin{array}{l}\text { Choosing appropriate music for the story was the best part of the job for } \\
\text { me. (S21) } \\
\text { I had so much fun while searching for music. (S9) }\end{array}$ & 9 & $\% 29$ \\
\hline Vocalization & $\begin{array}{l}\text { Vocalization was a really special experience for me. (S1) } \\
\text { I didn't expect that my voice would be liked so much. (S13) }\end{array}$ & 8 & $\% 25.8$ \\
\hline Creating a story & $\begin{array}{l}\text { It was a wonderful experience to create a unique story. (S19) } \\
\text { Though I was challenged in the process of creating the story, this was the } \\
\text { most amazing part of the activity. (S27) }\end{array}$ & 4 & $\% 12.9$ \\
\hline
\end{tabular}

\section{${ }^{*}$ S: Student}

At the end of the procedure, the students in the experimental group were asked about their satisfaction regarding the effectiveness of digital stories. All of them $(n=31)$ stated that they were satisfied with the application of digital story. 
As seen from Table, 35,4\% of the students were most content with visualization, $29 \%$ were content with music selection, $25,8 \%$ with vocalization, and $12,9 \%$ enjoyed creating the story most.

Table 8. Student Views on the Challenging Step of the Digital Storytelling Process

\begin{tabular}{|c|c|c|c|}
\hline Theme & Opinion/Code & f & $\%$ \\
\hline \multirow[t]{2}{*}{ Creating a story } & $\begin{array}{l}\text { It was quite a difficult experience to create a unique and meaningful } \\
\text { story. }(\text { S30) }\end{array}$ & 17 & $\% 54.8$ \\
\hline & Creating a story was the most challenging step.(S7) & & \\
\hline \multirow[t]{2}{*}{ Ensuring flow } & $\begin{array}{l}\text { It was quite difficult to provide flow between the music, pictures and } \\
\text { the story.(S6) }\end{array}$ & 15 & $\% 48.3$ \\
\hline & $\begin{array}{l}\text { The most challenging part for me was the Vocalization and } \\
\text { synchronization of the pictures. }(S 2)\end{array}$ & & \\
\hline \multirow[t]{2}{*}{ Visualization } & It was quite difficult to find images relevant to the topic. (S1) & 6 & $\% 19.3$ \\
\hline & I had a hard time finding their own images of authors and poets. (S26) & & \\
\hline \multirow[t]{2}{*}{ Vocalization } & It would have been better if vocalization hadn't been.(S12) & 4 & $\% 12.9$ \\
\hline & $\begin{array}{l}\text { I had difficulty while vocalizing my story. This part should not be } \\
\text { mandatory. (S13) }\end{array}$ & & \\
\hline \multirow[t]{2}{*}{ Selecting Music } & I must say that I had difficulty choosing music.(S2) & 2 & $\% 6.4$ \\
\hline & It is really hard to find suitable music for the story.(S21) & & \\
\hline
\end{tabular}

The students were asked for their opinion about the most challenging step of the storytelling process. Table 8 shows that $54,8 \%$ of the students indicated creating a story, $48,3 \%$ referred to ensuring the flow of the story, $19,3 \%$ the visualization, $12,9 \%$ the vocalization, and $6,4 \%$ pointed selection of music.

Table 9. Student Views on Benefits of Digital Stories

\begin{tabular}{|c|c|c|c|}
\hline Theme & Opinion/Code & $\mathbf{f}$ & $\%$ \\
\hline \multirow[t]{2}{*}{ Motivation } & $\begin{array}{l}\text { My active participation in the research process has increased my } \\
\text { motivation to learn. (S13) }\end{array}$ & 24 & $\% 77.4$ \\
\hline & I believe that I can make more beautiful stories. (S5) & & \\
\hline \multirow[t]{2}{*}{ Permanent Learning } & $\begin{array}{l}\text { I could comprehend the lesson better throughout the storytelling } \\
\text { process. (S7) }\end{array}$ & 21 & $\% 67.7$ \\
\hline & $\begin{array}{l}\text { The activities such as researching, repetition and visualization } \\
\text { helped me to better comprehend the course throughout the } \\
\text { process. (S11) }\end{array}$ & & \\
\hline \multirow[t]{2}{*}{$\begin{array}{l}\text { Technology } \\
\text { Skills }\end{array}$} & $\begin{array}{l}\text { I noticed that technology can be used in a useful way in this class. } \\
\text { (S19) }\end{array}$ & 19 & $\% 61.2$ \\
\hline & $\begin{array}{l}\text { Thanks to these applications, my ability to use technology increased } \\
\text { and I learned to make better use of technology. (S2) }\end{array}$ & & \\
\hline \multirow[t]{2}{*}{ Writing Skills } & This process has improved especially my writing skills. (S21) & 18 & $\% 58$ \\
\hline & Narrating the content has improved my writing skills. (S6) & & \\
\hline \multirow[t]{2}{*}{ Visual Literacy Skills } & $\begin{array}{l}\text { It is an important job to be able to select appropriate visuals for the } \\
\text { content.(S3) }\end{array}$ & 15 & $\% 48.3$ \\
\hline & $\begin{array}{l}\text { I can say that my visual awareness has increased in this process. } \\
\text { (S8) }\end{array}$ & & \\
\hline
\end{tabular}

The data in Table 9 demonstrate that the students in the experimental group expressed a favorable opinion regarding digital storytelling activities in general. Therefore, $77.4 \%$ of the students stated that digital narration increases the motivation, \%67.7 that it provides permanent learning,\% 61.2 said it develops their skills of using technology, 58\% improves their writing skills, and the last $48.3 \%$ stated that it increases visual literacy levels. 


\section{Results and Discussion}

This study was carried out to find out the effects of digital storytelling on academic achievement levels of students if there are any. Results showed that there was significant difference in the experimental group, who practiced digital storytelling, compared to the control group, who employed the existing traditional curriculum. The academic achievement test scores obtained by students in both groups increased as a result of the experiment. However, the scores of the experimental group were higher. The results suggest that digital storytelling has a positive effect on student achievement. Likewise, many studies in the literature demonstrate that digital storytelling improves academic achievement levels of students since it allows them to conduct research individually, participate actively in the learning process and learn through doing and experiences (Burmark, 2004; Barret, 2005; Robin, 2006; Jenkins \& Lonsdale, 2007; Ohler, 2008; Figg \& McCartney, 2010; Yang\&Wu, 2012; Hung, Hwang \& Huangi 2012; Yoon, 2013; Demirer, 2013).

Burmark (2004) also states that digital storytelling is an effective approach for students to obtain information, put forth new ideas and arrange the information and thus they can understand the subject better. In addition, Wang \& Zhan (2010) found out that the students who had already practised digital storytelling work during lessons could remember the course content more easily and in a meaningful way and that they are able to use this knowledge more easily in the future.

In this study, significant difference was found between the students' levels of learning motivation in favor of the experimental group, who practised digital storytelling activities during lessons while the control group kept using the existing curriculum. In particular, increased learning motivation was found in all sub-scales for both groups in the end of the experiment. Nevertheless, the increase was much higher in the experimental group. In addition relevant literature reveals that students become more motivated as a result of digital storytelling because they create a new product (Robin, 2006; Miller, 2009; Wang\&Zhan, 2010; Smeda, Dakich\&Sharda, 2010; Yang\&Wu, 2012; Hung, Hwang\&Huangi 2012; Demirer, 2013).

It was found out in our study that digital storytelling also has a positive effect on permanent learning. There is shared evidence in the literature that digital storytelling practices not only increase motivation and academic achievement but also contribute to permanent learning (Yang\&Wu, 2012; Wang\&Zhan, 2010; Dogan\&Robin, 2008;Wu \& Yang, 2008; Hung, Hwang \& Huang 2012; DiBlas vd., 2009).

The majority of the students reported positive views regarding the digital story application in the end of the experimental procedure. They stated that digital stories made the lesson funnier and more enjoyable and increased motivation and interest level by means of active participation in the learning process. This result seems to be similar with findings of a number of studies in the literature (Wu\&Yang, 2008; Yang\&Wu, 2012; Doğan \&Robin, 2008; Hung, Hwang\&Huang 2012; Hull\&Katz, 2006;Wake \&Modla, 2010; Reinders, 2011; Jakes\&Brennan, 2005).

Finally, the participants pointed out that they could improve their skills like speaking, listening, writing, using computer and visual skills thanks to the digital storytelling process. Abundant support is also provided by literature which note that digital stories develop students' speaking and communication skills (Borneman\&Gibson, 2011; Kervin\&Mantei, 2011; Dogan\&Robin, 2008); their visual literacy skills (Borneman \& Gibson, 2011; Brady\&Millard, 2012; Karakoyun, 2014; Çıralı Sarıca \& Koçak Usluel, 2016; Jakes\&Brennan, 2005); their listening skills (Solomon, 2010; Verdugo\&Belmonte, 2007); their writing skills (Borneman \& Gibson, 2011; Dogan \& Robin, 2008; Xu, Park\&Baek, 2011; Wake \&Modla, 2010; Sadik, 2008; Çıralı Sarıca \& Koçak Usluel, 2016), and their skills of using technology (Ballast, Stephens \& Radcliffe, 2008; Dogan\&Robin, 2008; Demirer, 2013; Heo, 2009; Karakoyun, 2014; Robin, 2006; Yüksel, 2011).

\section{Recommendations}

It requires a lengthy process to create digital stories. Therefore, this approach can be used for teaching particular subjects which students have difficulty in learning, rather than the entire school curriculum.

We think that digital storytelling could be more effective in increasing motivation and ensuring retention in learning in courses that require intensive data transfer.

Digital storytelling basically requires the ability to write original stories appropriate to the course content. In this process, teachers should act as guides and carry out works to relieve anxiety of writing.

\section{References}

Anastasiades, P. S., Vitalaki, E. \& Gertzakis, N. (2008). Collaborative learning activities at a distance via interactive videoconferencing in elementary schools: Parents' attitudes. Computers \& Education, 50, 1527-1539. https://doi.org/10.1016/j.compedu.2007.02.003. 
Ballast, K., Stephens, L. \& Radcliffe, R. (2008). The effects of digital storytelling on sixth grade students' writing and their attitudes about writing. In K. McFerrin et al. (Eds.), Proceedings of Society for Information Technology and Teacher Education International Conference 2008 (pp. 875-879). Chesapeake, VA: AACE.

Barrett, H. (2005). Researching and evaluating digital storytelling as a deep learning tool.[Online]:http://electronicportfolios.org/portfolios/SITEStorytelling2006.pdf.

Borneman, D. \& Gibson, K. (2011). Digital storytelling: Meeting standards across the curriculum in a WWII/Holocaust unit. School Library Monthly, 27(7), 16-17.

Brady, J., \& Millard, E. (2012). Weaving new meanings: evaluating children's written responses to a story telling resource package. Literacy, 46(1), 17-24. https://doi.org/10.1111/j.1741-4369.2011.00582.x

Burmark, L. (2004). Visual presentations that prompt, flash \& transform. Media and Methods, 40(6), 4-5.

Büyüköztürk, Ş., Akgün, Ö. E., Özkahveci, Ö. \& Demirel, F. (2004). Güdülenme ve Öğrenme Stratejileri Ölçeğinin Türkçe Formunun Geçerlik ve Güvenirlik Çalışması. [The Validity and Reliability Study of the Turkish Version of the Motivated Strategies for Learning Questionnaire] Educational Sciences: Theory \& Practice, 4(2), 207-239.

Cohen, L., Manion, L. \& Morrison, K. (2011). Research method in Education. London: Routledge.

Creswell, J.W. (2014). Research design, qualitative, quantitative and mixed methods approaches. (Edt. Demir SB.). Ankara: Eğiten Publications.

Çıralı Sarıca, H. \& Koçak Usluel, Y. (2016). The effect of digital storytelling on visual memory and writing skills. Computers \& Education, 94, 298-309. http://dx.doi.org/10.1016/j.compedu.2015.11.016.

Demirer, V. (2013). İlköğretimde e-öyküleme kullanımı ve etkileri. [Use of e-storytelling in primary education and its effects] . Unpublished doctoral dissertation. Necmettin Erbakan University, Institute of Education Sciences, Konya.

Di Blas, N., Garzotto, F., Paolini, P. \& Sabiescu, A. (2009). Digital storytelling as a whole-class learning activity: Lessons from a three-years project. In Interactive Storytelling (pp. 14-25). Springer Berlin Heidelberg. https://doi.org/10.1007/978-3-642-10643-9_5.

Dogan, B. \& Robin, B. R. (2008). Implementation of digital storytelling in the classroom by teachers trained in a digital storytelling workshop.

Figg, C. \& McCartney, R. (2010). Impacting academic achievement with student learners teaching digital storytelling to others: The ATTTCSE digital video project. Contemporary Issues in Technology and Teacher Education, 10(1), 38-79.

Foley, L. M. (2013). Digital storytelling in primary-grade classrooms. Unpublished doctoral dissertation, University of Arizona State, USA.

Glesne, C. (2013). Nitel araştırmaya giriş. [Introduction to qualitative research ]. (Çev. Ed. A. Ersoy \& P. Yalçınoğlu). Ankara: Anı Publishing.

Gyabak, K. \& Godina, H. (2011). Digital storytelling in Bhutan: A Qualitative Examination of New Media Tools Used to Bridge the Digital Divide in a Rural Community School. https://doi.org/10.1016/j.compedu.2011.06.009.

Heo, M. (2009). Digital Storytelling: An empirical study of the impact of digital storytelling on pre-service teachers self-efficacy and dispositions towards educational technology. Journal of Educational Multimedia and Hypermedia, 18(4), 405-428.

Huff, D. D. (2009). Every picture tells a story. Social Work, 43(6), 576-583.

Hull, G. A. \& Katz, M. (2006). Crafting an agentive self: Case studies of digital storytelling. Research in the Teaching of English, 41(1), 43-81.

Hung, C.M., Hwang, G.J. \& Huang, I. (2012). A project-based digital storytelling approach for improving students' learning motivation, problem-solving competence and learning achievement. Educational Technology \& Society, $15(4), 368-379$.

İnceelli, A. (2005). Dijital hikâye anlatımının bileşenleri.[The elements of digital storytelling ] The Turkish Online Journal of Educational Technology, 4(3), 132-142. 
Jakes, D. S. \& Brennan, J. (2005). Digital storytelling, visual literacy and 21st century skills. In Online Proceedings of the Tech Forum New York. [Online].

Jenkins, M. \& Lonsdale, J. (2007). Evaluating the effectiveness of digital storytelling for student reflection. In ICT: Providing choices for learners and learning. Proceedings ASCILITE Singapore.

Johnson, B. \& Christensen, L. (2004). Educational research: Quantitative, qualitative, and mixed approaches (2nd ed.). Needham Heights, MA: Allyn and Bacon.

Karakoyun, F. (2014). Çevrimiçi ortamda oluşturulan dijital öyküleme etkinliklerine ilişkin öğretmen adayları ve ilköğretim öğrencilerinin görüşlerinin incelenmesi .[ Examining the views of elementary school students and preservice teachers about digital storytelling activities in online environment]. Unpublished doctoral dissertation. Anadolu University Institute of Education Sciences, Eskişehir.

Karasar, N. (2012). Bilimsel araştırma yöntemi. [Scientific research method]. Ankara: Nobel Publishing.

Kearney, M. (2011). A learning design for student-generated digital storytelling. Learning, Media and Technology, 36(2), 169-188. https://doi.org/10.1080/17439884.2011.553623.

Kervin, L. \& Mantei, J. (2011). This is me: children teaching us about themselves through digital storytelling. Practically Primary, 16(1), 4-9.

Kocaman Karoglu, A. (2015b). Telling stories digitally: an experiment with preschool children. Educational Media International, 1-13 https://doi.org/10.1080/09523987.2015.1100391.

Kocaman Karoğlu, A. (2015). Öğretim sürecinde hikâye anlatmanın teknolojiyle değişen doğası: Dijital hikâye anlatımı. [The changing nature of storytellıng by means of technology in the instructional process: digital storytelling]. Educational Technology Theory And Practice, 5(2), 89-106 https://doi.org/10.17943/etku.29277.

Malita, L. \& Martin, C. (2010). Digital Storytelling as web passport to success in the 21st Century. Procedia Social and Behavioral Sciences, 2, 3060-3064. https://doi.org/10.1016/j.sbspro.2010.03.465.

McLellan, H. (2006). Digital Storytelling in Higher Education. Journal of Computing in Higher Education, 19(1), 65-79. https://doi.org/10.1007/bf03033420.

Miller, E. A. (2009). Digital storytelling. Unpublished master's thesis. University of Northern Iowa.

Nguyen, A. T. (2011). Negotiations and challenges in creating a digital story: The experience of graduate students. Unpublished doctoral dissertation, University of Houston, Houston, Texas.

Ohler, J. (2008). Digital storytelling in the classroom: New media pathways to literacy, learning, and creativity. Thousand Oaks, CA: Corwin Press.

Özçelik, D. A. (2010). Okullarda Ölçme ve Değerlendirme Öğretmen El Kitabı. [Measurement and Evaluation Handbook for School Teachers]. Ankara: Pegem Akademi Publishing.

Patton, M. Q. (2002). Qualitative research \& evaluation methods (3rd ed.). USA: SAGE Publication.

Reinders, H. (2011). Digital storytelling in the foreign language classroom. ELT World Online Blog.

Robin, B. \& Pierson, M. (2005). A multilevel approach to using digital storytelling in the classroom. In Society for Information Technology \& Teacher Education International Conference, 1, 708-716.

Robin, B. R. (2006). The educational uses of digital storytelling. In C. Crawford et al. (Eds.), Proceedings of Society for Information Technology \& Teacher Education International Conference 2006 (pp. 709-716). Chesapeake, VA: AACE.

Robin, B. R. (2009). Digital storytelling: A powerful technology tool for the 21st century classroom. Theory into Practice, 47(3), 220-228. https://doi.org/10.1080/00405840802153916.

Robin, B.R. (2012). An Evolving Framework for Teaching and Learning with Digital Storytelling. http://roderic.uv.es/handle/10550/25598.

Rossiter, M., and Garcia, P. (2010, March). Digital storytelling as narrative pedagogy. In Society for Information Technology \& Teacher Education International Conference, 1, 1091-1097.

Sadik, A. (2008). Digital storytelling: a meaningful technology-integrated approach forengaged student learning. Educational technology research and development, 56(4), 487-506. https://doi.org/10.1007/s11423-008-9091-8. 
Sawyer, C. B., \& Willis, J. M. (2011). Introducing digital storytelling to influence the behavior of children and adolescents. Journal of Creativity in Mental Health, 6(4), 274-283. https://doi.org/10.1080/15401383.2011.630308.

Smeda, N., Dakich, E. \& Sharda, N. (2010). Developing a framework for advancing e- learning through digital storytelling, M. Baptista ve M. McPherson (Ed.). IADIS International Conference, e-Learning 2010 (s.16-91). Freiburg, Germany.

Solomon, M. J. (2010). The need for (digital) story: first graders using digital tools to tell stories. University of Texas at Austin. Unpublished doctoral dissertation, University of Texas at Austin, USA.

Turgut, G. \& Kışla, T. (2015). Bilgisayar Destekli Hikâye Anlatımı Yöntemi: Alanyazın Araştırması. [The Use of Computer-aided Story in Education: Literature Review]. Turkish Online Journal of Qualitative Inquiry, 6(2), 97-121. https://doi.org/10.17569/tojqi.57305.

Verdugo, D. R. \& Belmonte, I. A. (2007). Using digital stories to improve listening comprehension with Spanish young learners of English. Language Learning \& Technology, 11(1), 87-101.

Wake, D. G. \& Modla, V. B. (2010). Language experience stories gone digital: Using digital stories with the LEA approach. Mentoring literacy professionals: continuing the spirit of CRA/ALER after, 50, 253-274.

Wang, S. \& Zhan, H. (2010). Enhancing teaching and learning with digital storytelling. International Journal of Information and Communication Technology Education (IJICTE), 6(2), 76-87. https://doi.org/10.4018/jicte.2010040107.

Wu, W. C. \& Yang, Y.T. (2008). The impact of digital storytelling and of thinking styles on elementary school students' creative thinking, learning motivation and academic achievement. K. McFerrin v.d. (Ed.), Proceedings of Society for Information Technology \& Teacher Education International Conference 2008 (s. 975-981). Chesapeake, VA: AACE.

Xu, Y., Park, H. \& Baek, Y. (2011). A New Approach Toward Digital Storytelling: An Activity Focused on Writing Selfefficacy in a Virtual Learning Environment. Educational Technology \& Society, 14(4), 181-191. https://doi.org/10.4135/9781452277479.n3.

Yang, Y. T. C. \& Wu, W. C. I. (2012). Digital storytelling for enhancing student academic achievement, critical thinking, and learning motivation: A year-long experimental study. Computers \& Education, 59(2), 339-352. https://doi.org/10.1016/j.compedu.2011.12.012.

Yoon, T. (2013). Are you digitized? Ways to provide motivation for ELL's using digital storytelling. International Journal of Research Studies in Educational Technology, 2(1), 25-34. https://doi.org/10.5861/ijrset.2012.204.

Yüksel, P. (2011). Using digital storytelling in early childhood education: a phenomeno logical study of teachers experiences. Unpublished doctoral dissertation. Middle East Technical University Institute of Education Sciences, Ankara. 